[Dobric, K. (2006). Drawing on Discourses: Policy Actors in the Debates over the National Certificate of Educational Achievement 1996-2000. New Zealand Annual Review of Education, 15, 85-109]

\section{Drawing on Discourses: Policy Actors in the Debates over the National Certificate of Educational Achievement 1996-2000}

\section{KAREN DOBRIC}

\section{Abstract:}

This article summarises a doctoral research project based on a theory of discourses used to throw light on a complex period of New Zealand educational history (1996-2000) when the adoption of policy for the National Certificate in Educational Achievement (NCEA) was undergoing vigorous discussion. Many layers of debate accumulated from the interaction of various sector groups, government agencies and policy actors, often invoking a very vocal media response. The approach taken was to analyse interviews with key policy actors by applying a theory of qualifications and assessment discourses to identify the ideological underpinnings of the debates over the introduction of a standardsbased assessment system.

$I_{\text {nis }}^{\mathrm{n}} \mathrm{nt}$ the early 1990s, the New Zealand Qualifications Authority (NZQA) planned to introduce into secondary education a National Certificate, using standards-based assessment. This brought to the fore a shift in the long historical debate over norm-referenced or standards-based assessment which had continued amongst educators, politicians and interest groups over the previous two decades. Initially discussions revolved around norm-referenced vs. criterion-referenced assessment, but new terminology to reflect new concepts was soon needed and introduced. The debate had involved differences of opinion over the suitability of national, external examinations (which were normreferenced) as the main mode of assessment in the country's system for certification. The change represented perhaps the most significant shift in secondary education policy for fifty years. A broader secondary school curriculum has developed from the unified qualification. A greater range of subjects may be credited - those that tend more towards the vocational end of the spectrum, as well as the more traditional academic subjects.

Until 2001 there were three main qualifications in the senior secondary school, one in each of the last three years: School Certificate, in Year 11; Sixth Form Certificate, in Year 12; and the University Bursaries examination, in Year 13. School Certificate and University Bursaries were, for many years, norm-referenced and statistically scaled at a national level.

The shift in thinking that was occurring in New Zealand is mirrored in the work of Young \& Spours (1998), who identified three challenges to raising participation and achievement in 14-19 education and training in England and Wales in the late 1990s. The first relates to engaging young people who are non-participants in education and training in developing their "learning capacities", rather than simply moving them through basic "getting into work" schemes that are often temporary solutions. The second is about raising expectations of success, particularly of "average" students, to include such strategies as supporting better learning, giving incentives to providers to offer more for students, and shifting to a focus on progression rather than selection. The third challenge is financial, and highlights the need to increase the funding required to achieve these goals. All of these challenges have been present in New Zealand during the shift in framing the purpose of senior secondary education from the selection of high-achieving students to the progression of all students.

The new NCEA qualification comprises three separate certificates at levels one, two and three on the National Qualifications Framework which was established as part of the education reforms of the early 1990s (Philips, 1998). All three qualifications are configured in a similar way, making it easier for the system to be understood. The more or less predictable failure rate of approximately 50 percent, associated with the old norm-referenced system, is no longer part of the New Zealand qualifications landscape. The new system makes it possible for all students to work progressively towards qualifications over time. This may involve a student achieving a level one qualification in Year 13, for example, if it is more applicable to the student's ability and motivation. Normally, Year 11 students study at level one, Year 12 at level two, and Year 13 at level three. 
The development of policy for a Standards-Based National Secondary Certificate (SBNSC), in due course named the NCEA, occurred against a backdrop of expected tension. Where any new qualifications are brought into a stable social framework, it is expected that there will be those who will support them, and those who will oppose them. As one interviewee said,

When you implement a reasonably systemic change like this, you've got to accept that there will be some trouble, there will be troubled waters. (Interviewee $\mathrm{X}$ )

In a policy framework he developed, Levin theorises that between the origins and legislation of policy there are the intermediate stages of policy proposal and policy adoption. Each of the four stages has a certain function, but some of them may be concurrent. Levin defines policy adoption as "the process of moving from an initial policy proposal to its final form in an approved piece of legislation, regulation or other vehicle" (2001, p. 115).

The initial proposal for an SBNSC led to a gazetted statement in 1992 that "it is government policy to introduce National Certificate, a new tertiary qualification. Credits towards the qualification will be gained at school or at other providers through the achievement of the learning outcomes of units of learning" (New Zealand Qualifications Authority, 1992). The adoption period followed; the latter part of which was concurrent with the legislation period 1998-2000. The first year of implementation of the policy for an SBNSC was 2002.

The NCEA policy has been portrayed by education officials in government agencies as "evolutionary", one example of this evolutionary change being a shift from a single "competent" standard to three levels: "achieved", "merit" and "excellence". Evolutionary theory in policy-making is described by Fischer: "As the policy goal proves to be a moving target, the question of whose interpretation of the goals and objectives to take as the actual public policy problematically remains open" (Fischer, 2003, p. 8). He explains that a policy which is initially clearly articulated may easily be derailed by carefully crafted problems of implementation identified by detractors, and the alternative is a rather "muddy", contested approach that can make derailing more difficult. There was no detailed policy initially "set in concrete" for the NCEA, so as Fischer suggests, the development towards implementation was likely to be a contested situation, nevertheless providing scope for a potentially strong policy to eventually be adopted and implemented.
Nearly ten years was spent contesting the adoption of the policy and it went through a number of changes due to the range and intensity of issues and debates that occurred. This is a lengthy period of time, but with a policy so central and critical to the education of young New Zealanders it could be regarded as positive and fitting that the evolutionary nature of the policy contributed to a necessary acceptance of intense public and government agency debate. This article identifies some of the underpinning tensions in those debates, but the issues themselves will not be the focus.

\section{Qualifications and Assessment Discourses}

Hajer has stated that "discourse analysis has changed the way that policy-making is studied" (Hajer, 2002, p. 1). What people say, and the ways in which people respond, have become much more important in recent years. Stories, such as how the dilemmas of policy implementation have been faced, need to be narrated and interpreted. Positions, counter-positions and justifications need to be considered. In clarifying the term discourse, Hajer explains that discussion and discourse are not the same: "discourse refers to a set of concepts that structure the contributions of a group of participants to a discussion." He says that argumentative discourse analysis (ADA), one well-used approach, is "about analysing politics as a play of "positioning" at particular "sites" of discursive production [and] tracks the way that people position one another through language use or the way that they are positioned through widely employed discourses." This is particularly important in the debates involved in the SBNSC policy development, as the whole secondary education sector was affected by the positioning that occurred through widely employed discourses.

Thompson says that at the level of argument, discourse analysis can "comprise explanations and chains of reasoning [that] may help to illuminate the ideological features of discourse by bringing out, not only their procedures of legitimation, but also their strategies of dissimulation" (Thompson, 1984, p. 136). At both the national level of policy actors and in local sites of schools and departments throughout the country, individuals and groups were involved in responding to, contributing to, and defending discourses that were used to argue the relative benefits or drawbacks of SBNSC policy.

Keeley and Scoones discuss policy change by saying that:

policy reflects political interests, that change reflects the actions of actor-networks, and that policy is a product of discourse. [These] can 
be taken together using a structuration argument, where discourses and interests are seen as shaping each other, and where both are additionally influenced by the actions of actor-networks. (Keeley \& Scoones, 1999, p. 1)

As the time-period for development of a policy extends, so too does the potential for complexity and shifting associations due to the on-going shaping and influence the authors describe.

\section{Macro-ideologies}

Qualifications can be considered scarce resources, and are described in the literature as "positional assets" (Brown, 2000). It is valid, then, to consider assessment and qualifications policy development from a class and ideological perspective. A key driver of political interests is political ideology, described here as macro-ideologies to discern four general ideological groupings at a macro-level; libertarianism, humanism, socialism and conservatism.

Michael Freeden, Director of the Centre for Political Ideologies at Oxford University, discusses liberalism, conservatism and socialism in his book Ideologies and Political Theory (Freeden, 1996). Freeden's use of liberalism as a major ideology is useful. However, he refers to "mistaken identities and other anomalies" when discussing liberalism. Given the importance of neo-liberalism (a type of libertarianism) to the global scene in Western democracies over the last two decades, particularly in economic terms, I will refer to "libertarianism" as the macro-ideology that is associated with the business middle class and economic capital. I add "humanism" as a fourth macro-ideology, as when looking at ideologies and perspectives of educators, I found it was difficult to locate them in the three ideologies that are most often identified. The term "humanism" appeared to be a more suitable fit.

To explain the relationships between these ideologies, I theorised two continua in a useful model; individual-society and equality-inequality. Socialism and conservatism have an emphasis on control at the level of society, socialism on the one hand fostering equality and social cohesion and conservatism on the other believing in inequality and preservation of social order. Humanism and libertarianism emphasise control at the level of the individual. Humanism accepts the notion of equality and highlights the importance of individual potential, whereas libertarianism acknowledges inequality and highlights the importance of individual freedom. In identifying humanism as a fourth macro-ideology, the model of two continua maintains a sense of balance, as can be seen in the inclusion of these notions in Figure 1 on p. 95.

\section{Assessment policy notions}

Broadfoot contends that it is vital to acknowledge both the technical and social aspects of assessment, and that in tracing the "essential themes which have informed recent assessment policy", the emphasis must be on the "assumptions which underpin these applications rather than the techniques themselves" (Broadfoot, 2001, p. 138). Three "broad policy strands" as proposed by Broadfoot are: "empowerment", "performativity", and "certification" initiatives. She states that

These three broad themes constitute the connecting narratives in the history of assessment policy in England and Wales during the last twenty-five years. At times, their essential incompatibility has been almost completely hidden. At other times, the stark choice between the different epistemologies on which they are based has been an explicit feature of policy debates. (Broadfoot, 2001, p. 139)

"Empowerment" relates to an "emancipatory" assessment discourse that involves: student participation in decision-making, the enhancement of learning through effective feedback, a focus on achievement and confidence-building, support for criterion-referenced rather than norm-referenced assessment practices; it subscribes to assessment practices that are transparent to students, thus improving the likelihood of achievement (Broadfoot, 2001). The processes include self-reflection, action-planning and the use of portfolios, and are part of a "substantial body of research which documents the powerful positive effects that can be achieved through the appropriate use of formative feedback and, particularly, self-assessment (Sadler, 1987; Black \& Wiliam, 1998)" (p. 139). These are initiatives that "cast assessment in the very different role of supporting learning." This assessment policy notion links to a humanist perspective, where education is encouraged as a means of human fulfilment.

Secondly, "performativity" is associated with a set of policies based on the assumption that "it is test results of one kind or another that are the best indicator of educational quality" (p. 143). Broadfoot argues that this discourse has taken over the "empowerment" discourse that was evident in the late 1980s and early 1990s in Wales and England. A key focus has been the increasingly "categoric" shift in the checking mechanism regarding the new National Curriculum, spurred on by a 
market forces driver with the goal of "competition between schools" (p. 142). Broadfoot's summary of "performativity" initiatives includes such features as "quality" standards, institutional quality, centralised decision-making, and a "neutral", technicist attitude to assessment (p. 138). The link here is to a libertarian approach where resources can be maximised through competition and through a focus on usefulness, technicism and instrumentalism.

A third grouping of initiatives comes under the heading "certification", which Broadfoot describes as "including the attestation of competency and selection - the more familiar territory of assessment purposes" (p. 139). These purposes link well to the traditional role of assessment as being for selection, or "sifting and sorting". In this sense "certification" fits with a conservative ideology, valuing excellence and status. In discussing the importance of recognising assessment as a "social process", she states that

there is a pressing need for a more socio-cultural understanding of assessment as a "social product", in which the values and traditions of particular cultures and theinterests of specific groups within them combine to produce particular definitions of quality or merit, as well as different policy emphases. (p. 152)

Based on her exhortation to understand assessment as a "social product" reflecting the variously combined values of different groups to produce different policy emphases, the three broad policy strands are applied, together with a fourth notion, to further ideas in the construction of a model of qualifications and assessment discourses.

Broadfoot's notions apply to three of the four macro-ideologies; humanism, libertarianism and conservatism. The fourth, socialism, lacks a matching assessment policy notion. I would argue that there is an explanation for this. Broadfoot is studying an historic pattern over twenty-five years, and in this time a norm-referenced system has dominated senior secondary education in England and Wales. Students who have dropped out of school, or failed to gain qualifications in senior secondary school, have not been participants in achievement to build self-confidence, have not contributed to test results that have indicated quality, nor have they been able to benefit from selection. They have not, then, been involved in "connecting narratives in the history of assessment policy" in relation to senior secondary qualifications. In the last two and a half decades it is reasonable to assume that the social class most likely to have been the least involved, and most marginalised, in the gaining of school qualifications is the labour class.

This lack of recognition of the labour class under a traditional qualifications and assessment system suggests a need to look further than Broadfoot's explanations for an appropriate notion. Bernstein states that education keeps the relationships between social structures stable, but is able to alter the structural relations of individuals. Such changes between individuals are

sufficient to create the impression of a general and probable movement ... [and as] social class is a major regulator of the distribution of students to privileging discourses ... [we need to consider] what shortfall, what limitation of pedagogic democratic rights, for whom and where, is a given society prepared to tolerate and, at any one time, accept. Those subject to this shortfall, this limitation ... must be given good reason ... if they are to have any confidence in the present and belief in the future. (Bernstein, 2000, p. XXv)

Bernstein is arguing that labour class students need to accept a disproportionate likelihood of education failure, clearly indicating that the education system itself provides the "good reason" for those "subject to this shortfall". On this basis, I would argue that the key policy notion for the labour class, and socialism as a macro-ideology, should be that of "opportunity", to indicate that which has been lacking and in which they have not been able to participate.

\section{Qualifications and assessment discourses and educational ideologies}

Based on the arguments above, there are four assessment policy notions from which to construct a model of qualifications and assessment discourses; empowerment, performativity, certification and opportunity. Using achievement to provide a key idea, they are explained as: fulfilment by achievement, linked to humanism with a focus on empowerment; usefulness of achievement, linked to libertarianism and focusing on performativity; excellence in achievement, linked to conservatism and focusing on certification; and recognition through achievement, linked to socialism, with a focus on opportunity. They are discussed with reference to educational ideologies in the following section.

The first discourse, fulfilment, concerns growth; based on the idea that education is about self-actualisation and meaning. Qualifications and assessment are about acknowledging what is learned, and a key 
idea is "fulfilment by achievement". By collaboration with teachers and responding to quality feedback about learning, a qualification can be earned. Assessment policy is about using students' talents to enhance their empowerment in learning, and within this discourse providing limited resubmission opportunities can be regarded as fair.

Trowler suggests that social reconstructionism is an educational ideology that "claims that education can be a force for positive social change, including (and perhaps especially for) creating an improved individual who is able critically to address prevailing social norms and help change them for the better" (1998, p. 63). This fits well with the key ideas of assessment contributing to growth and use of talents for empowerment in the fulfilment discourse. Trowler also notes that this educational ideology "favours a focus on subject disciplines, autonomous learning and personal development" (p. 63), which concurs with the notion of growth.

The discourse of usefulness concerns function and enterprise, based on the idea that education is about freedom and variety. Qualifications and assessment are about where people fit in economic sectors, and a key idea is the "usefulness of achievement". Through competition, performing better and working harder than other students, a qualification can be won. Within this discourse, assessment policy is about the application of learning to enhance performativity, and providing limited resubmission opportunities is regarded as fair.

Trowler summarises enterprise as an educational ideology which is associated with the political ideology of neo-liberalism, with an "emphasis on competitiveness in a market environment" (p. 64). Education is concerned with the development of people "to be good and efficient workers" (p. 62), with an emphasis on basic skills, new technology and greater effectiveness in teaching. Neo-liberalism, as associated with education, does not favour social planning or strategic direction, as this would be counter to the notion of market forces and the basic self-centredness of people; it is "anti-collectivist". It encourages diversity and choice, supports competition between students and between schools, and views parents as consumers. These ideas fit well with the function/enterprise priority of assessment in the usefulness discourse; the application of learning for performativity; and the libertarian macro-ideology.

The discourse of excellence concerns leadership, based on the idea that education is about knowledge and willpower. Qualifications and assessment are about fitness to win, and a key idea is "excellence in achievement". Through conflict over high stakes assessment and fear of failure, a qualification is awarded only for a restricted number. Assessment policy is concerned with enhancing educational status by the certification of learning, and providing only a single opportunity to pass an assessment is regarded as a fair situation. Failure is something to be expected and managed in the excellence discourse.

The discourse of recognition concerns enhancement, based on the idea that education is about belonging and taking part. Qualifications and assessment are about recognising potential, and a key idea is "recognition through achievement". By cooperation, attending school and completing work, it is possible to gain a qualification and/or entry to the next level of learning. Assessment policy is concerned with provision of educational choice to enhance opportunities for learning, and providing only a single opportunity to pass an assessment is regarded as fair.

Table 1 Series of concepts contributing to the four qualifications and assessment discourses (centre column, in capitals)

\begin{tabular}{|c|c|c|c|c|}
\hline $\begin{array}{c}\text { Macro- } \\
\text { ideologies }\end{array}$ & $\begin{array}{c}\text { Assessment } \\
\text { policy notion }\end{array}$ & $\begin{array}{l}\text { Qualifications } \\
\text { and assessment } \\
\text { discourse }\end{array}$ & $\begin{array}{l}\text { Importance of } \\
\text { achievement } \\
\text { to different } \\
\text { educational } \\
\text { ideologies }\end{array}$ & $\begin{array}{l}\text { Educational } \\
\text { ideologies }\end{array}$ \\
\hline conservatism & certification & EXCELLENCE & leadership & traditionalism \\
\hline libertarianism & performativity & USEFULNESS & function & enterprise \\
\hline humanism & empowerment & FULFILMENT & growth & $\begin{array}{l}\text { social recon- } \\
\text { structionism }\end{array}$ \\
\hline socialism & opportunity & RECOGNITION & enhancement & progressivism \\
\hline
\end{tabular}

Neo-conservatism is identified by Trowler as being the political ideology associated with the educational ideology of "traditionalism", through an emphasis on "order, hierarchies and cultural transmission" (p. 64). Neo-conservatism views people as naturally in conflict, and deems it the role of the government to control and maintain an ordered society. Pluralistic notions of power and people's freedom to choose are not favoured. Trowler states that an education policy example is an emphasis on "testing, ranking and sorting" (p. 57). One of traditionalism's key points is elitism, which he says "is justified in terms of the inherent difficulties of achieving a good education and the limited 
distribution of talent in society" (p. 62). This priority is compromised by too much emphasis on "equality of opportunity", which can result in standards being lowered by a fear of elitism. These points from Trowler correspond to the notion of assessment supporting leadership and status, together with conflict over high stakes assessment, in the excellence discourse.

Socialism is one important political ideology that is linked to the educational ideology of progressivism. Trowler describes progressivism as emphasising "personal development and social cooperation" (p. 64), and explains that it is student-centred, with personal development and choice being more important than subject knowledge and traditions. It "rejects elitism and favours mass access in higher education [and] the role of education is to give a 'step up' to disadvantaged individuals and groups in the largest possible number, not to reconstruct society" (p. 62). Socialism emphasises that the state exists for the benefit and promotion of all, not just a select few, and favours equity in terms of distribution of resources. The discourse of recognition corresponds to progressivism through its notion of enhancement, progression to new levels of learning and maximising opportunity.

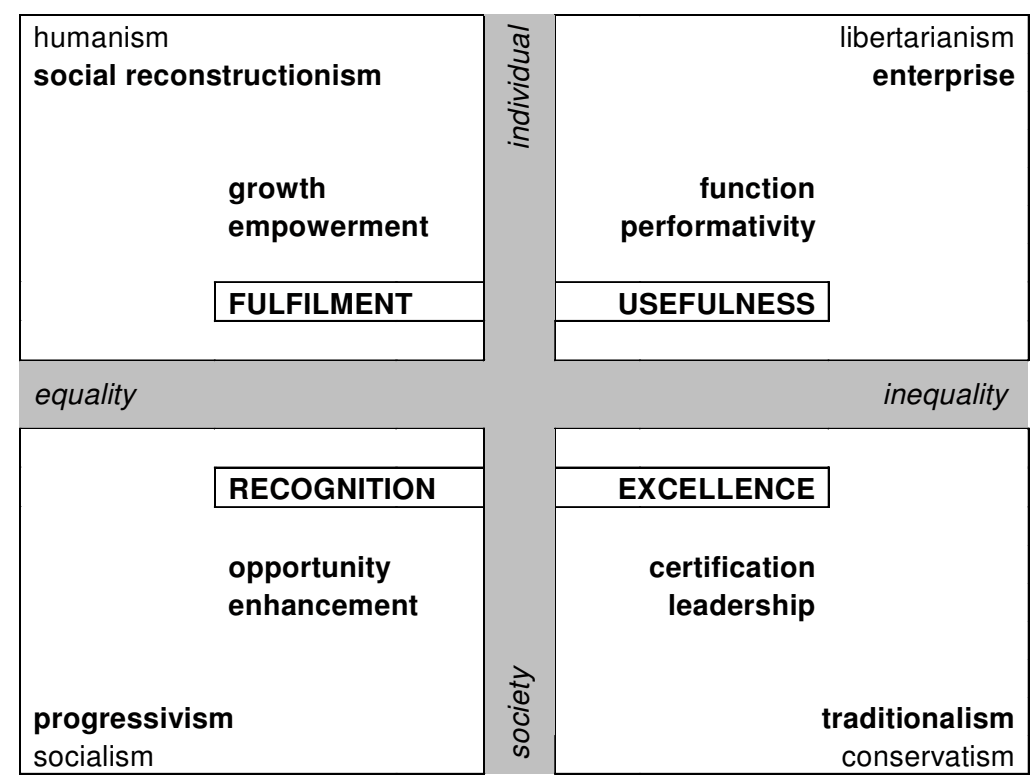

Figure 1 Overview of qualifications and assessment discourses (in capitals), associated concepts and continua

\section{RESEARCH}

This article is based on responses from 24 interviewees, considered to reflect the range of positions influencing the development of the policy, as well as including the most important policy makers in this area in the Ministry of Education during 2000, and in NZQA from earlier years. They were in fact the "actors" who had played a key role in the policy development, whether through their contribution as key policy players or critique as lobbyists. Key players provided insight into the complexities of the policy development, including the shift in SBNSC policy responsibility from NZQA to the Ministry of Education by 1998. Other interviewees providing critique as lobbyists were secondary school principals; academics; senior officials in the secondary teachers' union, the New Zealand Post-Primary Teachers' Association; and the policy analyst for a vocal conservative group.

\section{Methodology - Interviews with Policy Actors}

As the interviews took place in 2000 , the interviewees included people who had moved on from previous key roles to other places of work. The "group" was defined in terms of the interviewee's role between 1996 and 2000 in relation to the policy development; where there had been two or more significant roles the earlier role was used.

A range of questions relating to the policy development 1996-2000 was used in semi-structured one-hour interviews. The analysis of the interview transcripts was conducted as a form of content analysis, based on the utilisation of the various discourses. As Flick describes, qualitative content analysis is "one of the classical procedures for analysing textual material ... one of its essential features is the use of categories, which are often derived from theoretical models: categories are brought to the empirical material and not necessarily developed from it" (Flick, 2002, p. 190).

The prior-formulated deductive categories in this research are the discourse variables shown in Table 1 on p. 94. Each interview transcript was analysed using three key questions. Each key question had as responses three sets of four discourse variables referred to earlier. The questions and variables are:

- Why is achievement (in education) important? Leadership, function, growth or enhancement

- What assessment policy notion was present in the interview data? Certification, performativity, empowerment or opportunity 
- What discourse was used as justification (for qualifications and assessment)?

Excellence, usefulness, fulfilment or recognition

The analysis involved identifying and revealing the presence of arguments and justifications that drew on different discourses. In discussing the researcher's role in content analysis, Mayring identifies two orientations, one regarding the researcher as using more automated and regulated coding rules, the other as "a free interpreter of the material", using categorising rules more as guidelines (Mayring, 2001, p.

2 ). The latter is the approach used in this research, which took into account both the interview as a whole and a range of statements in the data with respect to each key question. The data analysis produced a "discourse indicator set" for each interviewee.

\section{Findings - Discourses Used by Policy Actors}

The discourse indicator sets produced in the analysis show that some policy actors drew on more than one discourse. Of the twenty-four interviewed, thirteen drew on one discourse and ten drew on two discourses. Four drew on the recognition discourse only; six drew on the fulfilment discourse only; three drew on the usefulness discourse only, and there were none who drew only on the excellence discourse.

The use of different discourses is illustrated in the following two examples, with three discourse variables in each set.

Interviewee F drew on the Fulfilment discourse only:

\section{Growth}

[Students] find their own level, ... they sort out what they want.

There will be some users who only want highly conventionally academic subjects with high achievement, and that's fair enough as long as it doesn't label everybody in the education system a failure.

\section{Empowerment}

When it's an overt [dual] track like that, what about the kid who [takes] the wrong track? ... it really needs to be multiple pathways.... [they are] liable to improve many more kids' achievement and that must help close some gaps, you would have thought.

\section{Fulfilment}

But at least though now [vocational unit standards] can ... all contribute in to the NCEA and kids will be able to do a programme composed of both, if it suits. And that's good.

(Interviewee F)
Interviewee J drew on both the Excellence and Usefulness discourses:

\section{Leadership}

And so this great vocational subsuming of academic things in the name of egalitarianism, you know, hasn't worked.

\section{Certification}

We don't believe [achievement standards are] what scholars want. They just want to be in there, having done their work, clear goal competing, I come 1st or 45th, happy. That's what it is. That's the way top scholars think.... they don't mind competing against people and why should we take that away from them?

\section{Usefulness}

I think that in the future jobs won't be actually going out to work. Jobs will be actually learning. You'll be paid to learn to get knowledge capital. And I think that's a very good thing.

(Interviewee J)

\section{Group membership}

Table 2 Groups to which interviewees belonged and qualifications and assessment discourses on which they drew

\begin{tabular}{|l|l|l|l|l|}
\hline \multirow{3}{*}{ Discourses } & EXCELLENCE & USEFULNESS & FULFILMENT & RECOGNITION \\
\cline { 2 - 5 } & certification & performativity & empowerment & opportunity \\
\cline { 2 - 5 } & leadership & function & growth & enhancement \\
\hline \multirow{2}{*}{ Groups } & Education & Education & & \\
& Forum & Forum & & \\
& Business & Business & & \\
& Roundtable & Roundtable & & \\
& Universities & Universities & Universities & \\
& Schools & Schools & Schools & Schools \\
& & NZQA & NZQA & NZQA \\
& & NZPPTA & NZPPTA & NZPPTA \\
& & Ministry of & Ministry of & Ministry of \\
& & Education & Education & Education \\
\hline
\end{tabular}

An analysis of the groups to which the policy actors belonged in the mid-to-late 1990s was undertaken to determine if any clear patterns showed up. Most policy actors, and therefore the groups to which they 
belonged, drew on more than one discourse, but amongst the complexity it was possible to detect some trends (See Table 2 on p. 98).

Table 3 Totals of discourse variables used by interviewees in each group

\begin{tabular}{|l|c|c|c|c|}
\hline Discourse & Excellence & Usefulness & Fulfilment & Recognition \\
\hline Education Forum & 4 & 2 & & \\
\hline Business Roundtable & 1 & 2 & & \\
\hline Universities & 1 & 2 & 3 & \\
\hline Schools & 1 & 2 & 2 & 1 \\
\hline NZQA & & 6 & 9 & 3 \\
\hline NZPPTA & & 3 & 7 & 4 \\
\hline Ministry of Education & & 5 & 1 & 9 \\
\hline
\end{tabular}

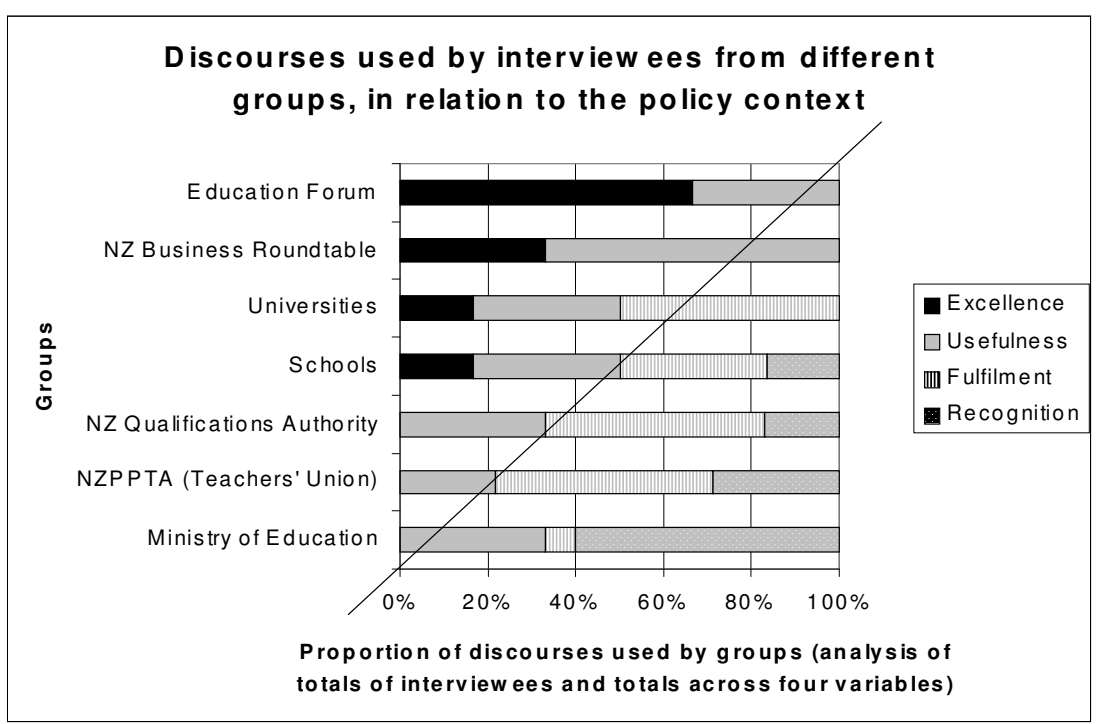

Figure 2 Discourses used by interviewees in the groups to which they belonged
There is a definite pattern to the discourses that different policy actors and groups most often used as justification and explanation. In general, as the proportion of excellence and usefulness discourses decreases, the proportion of fulfilment and recognition discourses increases (Table 3). The usefulness discourse was employed as justification by all groups. The schools group is the only group that drew on all four discourses.

Though the data set could be argued as small in terms of drawing generalisations, it has validity in the context of NCEA policy development in New Zealand because a significant proportion of the key policy actors and groups are included.

\section{Discussion}

The four contrasting discourses provide an explanation for the opposing opinions and attitudes in the NCEA debates. The analysis shows that each group drew on several discourses, rather than just a single one. Further complexities arose when a single discourse was used as justification by two or more groups, while at the same time their other discourses were in tension. The apparent contradictory nature of this pattern means that interpreting the chains of reasoning used and justifications advanced by each group becomes complicated.

This degree of complexity is a key reason for the on-going lack of resolution of the more contentious policy issues. Settlement in some areas of the policy debates has occurred through common justifications offered by different groups and policy actors - for example, the need to introduce levels of achieved, merit and excellence. During such periods of agreement, however, issues have been put to one side that have reemerged later - for example, attempts to gain agreement over resubmission guidelines.

All this makes it difficult for the education sector, not to mention the general public, to comprehend. I would argue that understanding which particular discourses were used by the different groups, and why they were used, is most important if one is to realise where the tensions arose.

Groupings of discourses, as shown in Figure 2 on p. 99, are between excellence and usefulness and between fulfilment and recognition. The more conservative group is in the top left part of the graph, and the government agency that needs to ensure that all students across society participate in compulsory education (the Ministry of Education) is located in the bottom right of the graph. 
The policy actors in the Ministry of Education, NZPPTA and NZQA drew on the usefulness, fulfilment and recognition discourses, indicating areas of commonality in the justifications they used in the policy debates. Although their discourse use was varied, the policy actors were supportive of a more unified senior secondary qualification, as can be seen by these comments:

The strength of this...is that individual subjects within an NCEA may come from either vocational or academic tracks and still be carried into the same qualification, and that was something that [in] the previous system...wasn't going to happen.

(Interviewee $\mathrm{H}$ )

There's a fundamental thing here. One of the policy drivers, and this is one of the policy issues that was decided by the Cabinet and it continues to be, is that the NCEA will be broadly recognising of the broad curriculum that we want.

(Interviewee $\mathrm{T}$ )

I have to say that the NCEA in broad terms met many of our policy and criteria, criteria we took out of the QFI Report and adopted as policy. All the other proposals that have been put out by the conservative lobby don't gain support because they all lack coherence. They all lack the ability to be integrated into something that would cover the range of abilities that kids present.

(Interviewee R)

These three groups were associated with secondary education at a systemic level involving the entire cohort of young people from Years 11-13 (the final three years of secondary school) and the structures supporting their education, including their teachers. With reference to NCEA policy development, areas of involvement by 2000 were: Ministry of Education, in developing policy for a new unified senior secondary qualification; NZQA, in implementing the policy; and NZPPTA, whose members (and other teachers who were non-members) were tasked with its operation at the school level. NZPPTA's support, however, was dependent on the necessary professional development, time and financial support for effective implementation and operation.

\section{Examples of discourses on which Ministry of Education drew are:}

USEFULNESS: What was not achieved through previous policies was

a single qualification integrated for the school sector.

(Interviewee U)
FULFILMENT: To the extent we are trying to do any re-engineering it's saying "We want you to be more explicitly thinking about what is the standard expected in the subject and just being much more explicit about that in a way the teachers know, the profession knows, the parent knows, the student knows".

(Interviewee I)

RECOGNITION: [There was] concern about the numbers of students coming out without any qualifications [and] then getting lost in the system and nobody was picking them up.

(Interviewee G)

Examples of discourses on which NZPPTA drew are:

USEFULNESS: I think we were absolutely wrong that it was possible to break down the barriers between the vocational and the academic. ... I think we had rose-tinted spectacles on and we were putting the principal issue of recognition of achievement ahead of some common sense constraints that actually exist.

(Interviewee S)

FULFILMENT: [If you're] the country's 2 millionth lawyer who can't find a job, you've succeeded. But if you become the much wanted technician of whom there are absolutely none, it's because you're a failure...we overinflate some types of achievement beyond their actual utility, and we debase others which we actually desperately need to value.

(Interviewee E)

RECOGNITION: And they were also adamant that people should be able to mix their travel and tourism with their calculus. They should be able join up lots of things....

(Interviewee C)

Examples of discourses on which NZQA drew are:

USEFULNESS: There had been considerable drive from the Employers Federation around requirements of better reporting that examination marks/grades didn't tell them enough about the candidates to assist them in making employment decisions.

(Interviewee Q)

FULFILMENT: You come along to School Certificate and then you have this barrier of School C.... Fail that first step. And so one of the key decisions was hey, this NCEA Level 1 should be a stepping stone into qualification so you had this sort of idea here that you can steer from here, you can take this pathway that will then lead on.

(Interviewee A) 
RECOGNITION: I mean, generally speaking the immediate block of support of standards-based assessment were the lower performing... lower socio-economic profile schools. The ones that weren't the winners in the old system.

(Interviewee X)

"Schools" is the only group where all four discourses - excellence, usefulness, fulfilment and recognition - were drawn upon, indicating that of all the groups "schools" demonstrated the greatest diversity in attitudes and opinions. During 2002-2004, a number of secondary schools chose not to offer the NCEA qualification solely in their schools, but to implement Cambridge International Examinations as well. This situation confirms the variation of discourse use in schools during the earlier policy adoption period 1996-2000. A feature of New Zealand secondary schools is their self-managing status, providing for a degree of competition amongst them, and allowing for elements of resistance against centralised state planning and decision-making to exist.

There was, however, general support in the schools group for a more unified senior secondary qualification, as can be seen here:

The NCEA will actually do everything for everybody.

(Interviewee M)

Separate academic and vocational qualifications has allowed for the emergence of academic / vocational divide.

(Interviewee $\mathrm{N}$ )

Examples of discourses used by the "schools" group are:

USEFULNESS: NZ context, values, size, history .... Both types of credits going towards one qualification fits so well into NZ culture. (Interviewee N)

FULFILMENT: Education's not a race. Life's not a race. You don't have to race through it. If it takes you an extra six months because you want to do a few more standards, how can that be bad?.... I can't see how we're doing society a service if all we ever do is rank.

(Interviewee $\mathrm{M}$ )

RECOGNITION: Students who in the past would not have had any qualification whatsoever in our Transition Programme getting the employment skills, unit standards and all of those. It's just a wonderful story.

(Interviewee $\mathrm{M}$ )

EXCELLENCE: You could actually assess outcomes based assessment,...report a percentage,....and the number of credits that somebody could get [all] out of an external examination. (Interviewee N)

The "universities" group used three discourses, excellence, usefulness and fulfilment. This may indicate that universities generally tend to place lesser emphasis on opportunity, enhancement and recognition. But they demonstrated some support for a more unified senior secondary qualification, as can be seen here:

Education Forum - Academic Rationalist view - belief in the integrity of a subject etc. "traditional". There is a place for that, but they do so at the exclusion of most of the population.

(Interviewee L)

There was pressure for one coherent unified qualification for senior secondary school. Try and bring all this diversity into one framework. (Interviewee W)

Examples of discourses used by the "universities" group are:

USEFULNESS: NCEA [as standards-based assessment] won't make the slightest bit of difference re "Closing the Gaps". (Interviewee L)

FULFILMENT: There was pressure within the PPTA for unit standards to be retained for what it was doing for student achievement.

(Interviewee W)

EXCELLENCE: Assessment drives teaching and learning though, being high stakes.

(Interviewee L)

The New Zealand Business Roundtable (NZBR), and The Education Forum groups drew on only two discourses; the excellence and usefulness discourses. The NZBR is "founded on the belief that a healthy, dynamic business sector and open and competitive markets are fundamental to the achievement of a prosperous economy and fair society" (New Zealand Business Roundtable, 2004, p. 1). The Education Forum, formed in the early 1990s, is a conservative education lobby group with close links to the Business Roundtable. It describes itself as an "association of individuals who have a common concern for the future direction of New Zealand education" (Education Forum [NZ], 1999 , p. 4). Some of their stated principles include a commitment to excellence, competition, high standards of assessment, and parental choice (Education Forum, 1995). 
The excellence discourse had been hegemonic in senior secondary qualifications and assessment in New Zealand society for decades, and the proposal of a new qualification sourced in other discourses was a threat to some. Interviewee $\mathrm{K}$ regards qualifications as a means of access to status, a reference to the assessment policy notion of certification, and drawing on the excellence discourse. This is further sustained by their critique of ideology that gets "rid of perceived status differences" (Interviewee K). Support by this group for academic senior secondary school examinations was for similar reasons - the qualifications would remain valued through the "setting of high standards", "excellence", and avoidance of "dumbing down". There was no support for a more unified senior secondary qualification, as can be seen here:

I think that we should have looked at the 6th Form and had a look at how we could have actually differentiated the 6th Form between academic courses and vocational courses ....The reasoning [behind the qualification having both types of credit] is a straight egalitarian principle.

(Interviewee J)

I don't see any reason whatsoever [for both types of credit going towards one qualification]. They've got one framework, they want qualifications to be transportable, they want to be able to get a qualification here and dump it there and it counts as credits...I think it is one of the weaknesses of the whole thing actually.

(Interviewee V)

In England...about age 14 is about the beginning of serious curriculum differentiation. My gut feel is that 14 or 15 is probably where you begin.

(Interviewee K)

Examples of discourses used by The NZBR and The Education Forum groups are:

EXCELLENCE: I think people saw that [NCEA] wasn't going to work for academic subjects where you can't just tick off [and] say "it's done". But it became hijacked by what I'd describe as leftist social engineering principals and because they brought in too much PPTA. (Interviewee J)

EXCELLENCE: You can be elite in sports and admit it, but not academically. It's just bizarre, the whole thinking of these people...This was one of the discussions..."What are we going to do with the bottom $30 \%$ ?" Well look, that's fine, we've got to help those kids but not to the exclusion of those in the middle and at the top. So I think they're going about it the wrong way. Instead of trying to drag the bottom up, we bring the top down basically.

(Interviewee V)

USEFULNESS: If you do a vocational programme it means almost certainly that you're going to drop off education earlier and your occupational opportunities are thereby more restricted .... It's what you can do with the qualification that gives it status. And the relative status of so-called academic qualifications versus so-called vocational qualifications is that the academic qualifications almost always take you further...ultimately leading to higher paid jobs.

(Interviewee K)

USEFULNESS: Alternative form[s] of assessment .... I guess it's that it's okay at a lower level, it's okay for more vocationally, because there is a difference, whether you like it or not - there's a difference between vocational and academic.

(Interviewee V)

Capper (1997) reflects the above views in saying that educational qualifications are related to commodities or possessions that can be exchanged for status and wealth, and that the "National Qualifications Framework is a fundamentally new way of doing this, and the tensions associated with its introduction are more about the profound changes in the allocation of power and status than they are to do with technical problems" (Capper, 1997, p. 3). Hood suggests that the old system of assessment suited some schools so well that, "as one chairman of the board of a private school confided to me, schools like his would fight against the [National Qualifications] Framework as it represents a serious threat to their status and reputation" (Hood, 1998, p. 106).

SBNSC policy developed from the consultation documents and reports of the mid-late 1980s and early 1990s, and it sought to span the upper end of compulsory education as well as the lower levels of post-compulsory education and training. In this regard it contained a policy driver of bridging the academic-vocational divide. A key policy solution that had developed by the early 1990s was the credit/no credit option, which weakened the hegemony of the excellence discourse by the intention to include conventional school subjects in the credit/no credit option of SCNSC qualifications. A significant threat was the policy solution of offering an opportunity for reassessment that was part of the 
SBNSC policy. For a discourse (excellence) that accepts a single opportunity as being fair for the purpose of high stakes assessment, the notion of an opportunity to resubmit runs counter to the way assessment, as excellence, is defined. In the unified system proposed for New Zealand, however, reassessment opportunities were a key underpinning concept in support of progression.

The process of selection was vital to the conservative groups, and the scholarship examination was strongly argued for (as noted in years of debate in the early 1990s, recorded in NZQA Board minutes) in order to maintain selection at the highest level of academic achievement. In contrast, those supporting SBNSC policy saw more significant opportunities within a unified framework that supported the notion of progression, providing opportunities for all students to achieve and advance to employment, further education and training without the expectation that failure was a necessary component of this experience.

\section{Conclusion}

In the NCEA policy context, policy actors have cited information and arguments which have justified their perspectives in order to establish, maintain, challenge and affect influence. This contestation can be located in one or more of four qualifications and assessment discourses which are informed by assessment policy notions and underpinned by educational ideologies.

This article has argued that through the analysis of qualifications and assessment discourses in the context of the NCEA policy adoption period 1996-2000, the actions of policy actors and the groups to which they belonged can be better understood. Although power and political struggles may be key to understanding the contestation over the development of policy for standards-based national secondary certificates, it is through discourse analysis that the contributions of all policy actors and groups can be acknowledged. Discourse analysis provides for a more informed level of understanding and can serve to make policy-making more transparent, thus contributing to more positive decision-making processes during periods of intense debate over the adoption of educational policy.

\section{References}

Bernstein, B. (2000). Pedagogy, symbolic control, and identity: Theory, research, critique (Rev. ed.). Lanham, Maryland: Rowman \& Littlefield Publishers.
Black, P., \& Wiliam, D. (1998). Assessment and classroom learning. Assessment in Education, 5(1), 7-74.

Broadfoot, P. (2001). Empowerment or performativity? Assessment policy in the late twentieth century. In R. Phillips \& J. Furlong (Eds.), Education, Reform and the State: Twenty-Five Years of Politics, Policy and Practice (pp. 136-155). London and New York: Routledge/ Falmer.

Brown, P. (2000). The globalisation of positional competition? Sociology, 34(4), 633-653.

Capper, P. (1997). Commentary on NZQA assessment stocktake report (Consultation Draft). Unpublished manuscript, Wellington.

Education Forum. (1995). Education Forum. The Education Digest, 3(3).

Education Forum.(NZ). (1999, October). Education Forum Newsletter, 2.

Fisher, F. (2003). Reframing public policy. Discursive politics and deliberative practices. New York: Oxford University Press.

Flick, U. (2002). An introduction to qualitative research (2nd ed.). London: Sage.

Freeden, M. (1996). Ideologies and political theory: a conceptual approach. Oxford: Clarendon Press; New York: Oxford University Press.

Hajer, M. A. (2002). Discourse analysis and the study of policy making. European Political Science [Electronic Version], 2(1).

Hood, D. (1998). Our secondary schools don't work anymore: Why and how New Zealand schooling must change for the 21st century. Auckland: Profile Books.

Keeley, J., \& Scoones, I. (1999). Understanding environmental policy processes: A review (IDS Working Paper 89). Brighton: Institute of Development Studies.

Levin, B. (2001). Reforming education: From origins to outcomes. London and New York: Routledge/Falmer.

Mayring, P. (2000). Qualitative content analysis [28 paragraphs]. Forum Qualitative Sozialforschung/Forum: Qualitative Social Research [On-line Journal], (June, 1(2)). Retrieved 17 March, 2006, from

$<$ www.qualitative-research.net/fqs-texte/2-00/2-00mayring-e.htm >

Mayring, P. (2001). Qualitative content analysis - Research instrument or mode of interpretation? Paper (short version) presented at the 2nd Workshop on Qualitative Research in Psychology at Blaubeuren, University of Tuebingen, October 2001. 
Retrieved 17 March, 2006, from

<www.uni-tuebingen.de/qualitative-psychologie/t-ws01/Mayring_en.htm>

New Zealand Qualifications Authority. (1992). National Certificate Implementation of general education units in the senior secondary school. New Zealand Education Gazette, 71(1), 4-5.

New Zealand Business Roundtable. (2004). Statement of purpose.

Retrieved 27 November, 2004, from

$<w w w . n z b r . o r g . n z /$ statement_of_purpose.asp $>$

Philips, D. J. (1998). The switchmen of history: The development of a unitary qualifications framework. (Vols. 1-3). Unpublished PhD thesis, Victoria University of Wellington.

Sadler, R. (1987). Specifying and promulgating achievement standards. Oxford Review of Education, 13(2), 191-209.

Thompson, J. B. (1984). Studies in the theory of ideology. Cambridge: Polity.

Trowler, P. (1998). Education policy: A policy sociology approach. Eastbourne: Gildredge Press.

Young, M., \& Spours, K. (1998). 14-19 education: Legacy, opportunities and challenges. Oxford Review of Education, 24(1), 83-97.

\section{The author}

Karen Dobric has worked in staff and programme development, secondary and tertiary teacher education and secondary teaching. She graduated with a Doctor of Education degree in 2005. Her research interests include academic/vocational definitions in secondary and tertiary curricula, quality issues in secondary and tertiary assessment practice, senior secondary education provision, and the development of policy in these areas.

\section{Acknowledgement}

It is with thanks that I acknowledge Dr Joce Jesson for her encouraging and insightful feedback regarding my early thoughts of a relational model of educational ideology, which has matured over time into a more complex model of notions of discourse. I am most grateful for her support as some fledgling ideas started to grow and take wing. 